\title{
GENETIC VARIATION AMONG Pinus patula POPULATIONS ALONG AN ALTITUDINAL GRADIENT. TWO ENVIRONMENT NURSERY TESTS
}

\author{
VARIACIÓN GENÉTICA ENTRE POBLACIONES DE Pinus patula EN UN GRADIENTE \\ ALTITUDINAL. ENSAYO DE VIVERO EN DOS AMBIENTES
}

\author{
Cuauhtémoc Sáenz-Romero ${ }^{{ }^{*}}$, Lorena F. Ruiz-Talonia ${ }^{1}$, Jean Beaulieu ${ }^{2}$, \\ Nahum M. Sánchez-Vargas ${ }^{1}$ and Gerald E. Rehfeldt ${ }^{3}$
}

\begin{abstract}
${ }^{1}$ Instituto de Investigaciones Agropecuarias y Forestales, Universidad Michoacana de San Nicolás de Hidalgo (IIAF-UMSNH). Km 9.5 Carretera MoreliaZinapécuaro. 58880, Tarímbaro, Michoacán, México. Tel: +(52)(443) 334-0475 ext. 118, Fax ext. 200. ${ }^{2}$ Centre Canadien sur la Fibre de Bois, Service Canadien des Forêts, Ressources Naturelles Canada. 1055 rue du P.E.P.S.10380, Succ. Sainte-Foy, Québec QC, G1V 4C7, Canada. ${ }^{3}$ Forestry Sciences Laboratory, Rocky Mountain Research Station, USDA Forest Service, 1221 S. Main, 83843, Moscow, Idaho USA.
\end{abstract}

* Autor para correspondencia (csaenzromero@gmail.com).

\section{SUMMARY}

Aiming to determine if there is genetic differentiation among Pinus patula Schiede et Chamizo populations along an altitudinal gradient and for quantifying the genotype $x$ environment interaction, 13 Pinus patula populations were sampled from forests of the Native Indian Community of Ixtlán de Juárez, Oaxaca, state of México, along an altitudinal gradient $(2400 \mathrm{~m}$ to $3000 \mathrm{~m})$, cones being collected on groups of trees on every $50 \mathrm{~m}$ of altitudinal step). Seedlings were grown in tree pots in two different environments: a shadehouse located at Ixtlán de Juárez, and in a greenhouse and then in a shadehouse situated at Quebec, Canada. Total seedling height was measured at 6-months of age in both locations. Results indicated that populations differed significantly $(P=0.025)$, but there was no significant genotype $x$ environment interaction $(P=$ 0.426; $B$ type genetic correlation $=0.93$ ). Population from $2650 \mathrm{~m}$ (middle altitude) exhibited the best height. Although not definitive, our study suggests the presence of a weak altitudinal pattern of variation in seedling height, where populations originating of midaltitudes exhibit the highest growth potential while populations from the upper and lower altitudinal extremes exhibit the lowest growth potential.

Index works: Pinus patula, genotype x environment interaction, commercial plantations, provenances, altitudinal genetic variation.

\section{RESUMEN}

Con el objetivo de determinar si existe diferenciación genética entre poblaciones de Pinus patula Schiede et Chamizo a lo largo de un gradiente altitudinal $y$ de cuantificar la interacción genotipo $x$ ambiente, 13 poblaciones de Pinus patula se muestrearon en bosques de la Comunidad Indígena de Ixtlán de Juárez, Estado de Oaxaca, México, a lo largo de un gradiente altitudinal $(2400 \mathrm{~m}$ a $3000 \mathrm{~m}$, mediante colecta de conos en grupos de árboles por cada $50 \mathrm{~m}$ de intervalo altitudinal). Las plántulas crecieron en contenedores rígidos en dos ambientes diferentes: una casa de sombra en Ixtlán de Juárez, y en un invernadero y después en una casa de sombra situada en Quebec, Canadá. La altura total de plántula fue medida a los seis meses de edad en ambas localidades. Los resultados indicaron que las poblaciones difieren significativamente $(P=0.025)$, pero que no hay interacción genotipo $x$ ambiente $(P=0.426$; Correlación genética tipo $B=0.93)$. La población de $2650 \mathrm{~m}$ (altitud media) exhibió el mejor crecimiento en altura. $\mathrm{Si}$ bien no de manera definitiva, este estudio sugiere la presencia de un débil patrón altitudinal de variación en altura de planta, en donde las poblaciones originadas de altitudes intermedias exhiben el potencial de crecimiento más alto y las poblaciones de los extremos altitudinales superior e inferior, exhiben el potencial más bajo.

Palabras clave: Pinus patula, interacción genotipo x ambiente, plantaciones comerciales, procedencias, variación genética altitudinal.

\section{INTRODUCTION}

Pinus patula Schiede et Chamizo is one of the most productive pine species native to México. Its straight stem form, wood of moderate density, low extractives content, long tracheids, high fiber coarseness, low lignin content and high growth rate, confer to this species a very high potential value to be grown as intensively managed plantations in the country (Dvorak et al., 2000; Velázquez-Martínez et al., 2004), as well as for ecological restoration of degraded sites in the regions where it is naturally distributed. Additionally, this species has been planted extensively as an exotic in southern and western Africa and in western South America (Dvorak et al., 2000). 
Selection of the best provenances for intensive plantations is relevant for the Forestry Office of the Native Indian Community of Ixtlán de Juárez, located in the north of Oaxaca State, southern México. This community conducts certified sustainable forest management (Martínez-Guzmán and Colín-Castillo, 2003), in a pine-oak forest were the most productive species among the dominant pines is $P$. patula (Dvorak et $a l ., 2000$ ). Early selection offers a possibility to shorten breeding cycles and to save resources by reducing the number of provenances and families to be tested in the field (Zobel and Talbert, 1992; Viveros-Viveros et al., 2005). However, the efficiency of early selection depends on the strength of age-age correlations (Lambeth et al., 1983; Adams et al., 2001).

Conifer populations may often differentiate genetically along altitudinal gradients in response to differential selection pressures (Rehfeldt, 1991; Rehfeldt et al., 1999). The understanding of such patterning of genetic variation is needed to delineate seed and seedlings transfer guidelines to match genotypes with planting sites that will allow them for best performance under contemporary and future climates (Saenz-Romero et al., 2006).

The objectives of this study were: (1) To determine whether there is genetic differentiation for plant height among $P$. patula populations along an altitudinal gradient; (2) To determine whether there is genotype $\mathrm{x}$ environment interaction; and (3) To generate information that could be used later to calculate age-age correlations.

\section{MATERIALS AND METHODS}

Wind-pollinated cones were collected from 11 randomly selected trees from each of 13 Pinus patula natural stands distributed along an altitudinal transect from 2400 to $3000 \mathrm{~m}$ of altitude, in the forests of the Native Indian Community of Ixtlán de Juárez, state of Oaxaca, México. Sampled stands were separated by an altitudinal interval of approximately $50 \mathrm{~m}$. Hereafter, the group of trees on which cones were collected in each stand, is named populations while the geographic location of the population is called provenance (Table 1). Trees within populations were selected randomly in order to have a good representation of the genetic variability of each population, and to avoid bias toward trees with superior phenotypes (regarding commercial traits). Seeds were manually extracted from the cones of each tree and then bulked by provenance. Seeds were stored at $4{ }^{\circ} \mathrm{C}$ until they were ready for germination.
Table 1. Geographical and altitudinal localization of 13 Pinus patula Schiede \& Cham. populations sampled along an altitudinal transect at Ixtlán de Juárez, state of Oaxaca, México.

\begin{tabular}{cccc}
\hline Site & Latitude N & Longitude W & Altitude (m) \\
\hline 1 & $17^{\circ} 22.270^{\prime}$ & $96^{\circ} 26.987^{\prime}$ & 3000 \\
2 & $17^{\circ} 23.154^{\prime}$ & $96^{\circ} 27.402^{\prime}$ & 2950 \\
3 & $17^{\circ} 23.185^{\prime}$ & $96^{\circ} 27.839^{\prime}$ & 2900 \\
4 & $17^{\circ} 21.793^{\prime}$ & $96^{\circ} 27.399^{\prime}$ & 2850 \\
5 & $17^{\circ} 21.795^{\prime}$ & $96^{\circ} 27.562^{\prime}$ & 2800 \\
6 & $17^{\circ} 23.004^{\prime}$ & $96^{\circ} 28.577^{\prime}$ & 2750 \\
7 & $17^{\circ} 21.749^{\prime}$ & $96^{\circ} 27.880^{\prime}$ & 2700 \\
8 & $17^{\circ} 23.162^{\prime}$ & $96^{\circ} 28.938^{\prime}$ & 2650 \\
9 & $17^{\circ} 23.059^{\prime}$ & $96^{\circ} 28.861^{\prime}$ & 2600 \\
10 & $17^{\circ} 22.902^{\prime}$ & $96^{\circ} 28.902^{\prime}$ & 2550 \\
11 & $17^{\circ} 22.808^{\prime}$ & $96^{\circ} 29.067^{\prime}$ & 2500 \\
12 & $17^{\circ} 22.679^{\prime}$ & $96^{\circ} 28.986^{\prime}$ & 2450 \\
13 & $17^{\circ} 22.353^{\prime}$ & $96^{\circ} 28.971^{\prime}$ & 2400 \\
\hline
\end{tabular}

In order to determine whether there is genotype $\mathrm{x}$ environment interaction, a provenance test was established at two locations: (a) The forest nursery of the Native Indian Community of Ixtlán de Juárez (17 $17^{\circ}$ 50" LN, 96 29 ' 14" LW, 2030 masl, annual average temperature of $16.8^{\circ} \mathrm{C}$, and annual average precipitation of $964 \mathrm{~mm}$ ), to which we will hereafter refer as "Ixtlán"; and (b) The research facilities of the Laurentian Forestry Centre of Natural Resources of Canada, Quebec City, Quebec, Canada (46 ${ }^{\circ} 47^{\prime} \mathrm{LN}, 7^{\circ}$ 17' LW, 27 masl, annual average temperature of $5.0{ }^{\circ} \mathrm{C}$, and annual average precipitation of $1173 \mathrm{~mm}$ ), to which we will refer as "Quebec".

At both locations seedlings were grown following locally standard procedures to promote a healthy development. In Quebec, seedlings stayed in the greenhouse longer than usual in comparison to local species, to prevent damage by Spring cold temperatures. Culture of the seedlings was done according to the following schedule in each location:

\section{For the Quebec test}

1) Seeds were washed with running tap water for $48 \mathrm{~h}$, stratified for $17 \mathrm{~d}$ at $4{ }^{\circ} \mathrm{C}$ and sowed on 11-12 April, 2007, in $320 \mathrm{~cm}^{3}$ containers filled with a mix of Farfarf@'s peat-moss and Holiday®'s vermiculite (168 L of peat-moss per $8.6 \mathrm{~kg}$ of vermiculite). Seeds were covered with a $0.5 \mathrm{~cm}$ layer of inert silicate, to avoid washing out of the seed by irrigation.

2) Seedlings were arranged in a randomized complete block design with 18 blocks, where each provenance was represented by a three-seedling row plot. One border row per block as well as two extra blocks containing surplus 
seedlings were placed as protection rows for reducing the border effects on the experimental material.

3) Seedlings were grown during four months in a greenhouse; temperature of $24{ }^{\circ} \mathrm{C}$ during the day and 18 to $20^{\circ} \mathrm{C}$ during the night; cycles of $16 \mathrm{~h}$ of light and $8 \mathrm{~h}$ of darkness; watering and fertilization was applied as needed.

4) Four months old seedlings were transferred to an outdoor shadehouse in August 2007, to promote bud setting, maintaining the initial experimental design.

\section{For the Ixtlán test}

1) Seeds were sowed on 21-22 November, 2007, in 380 $\mathrm{cm}^{3}$ containers filled with a mixture peat-moss, vermiculite and agrolite (50:25:25).

2) Seedlings were arranged in a randomized complete block design with three blocks, and within a block each provenance was represented by 49 seedlings-square plot. Containers with surplus seedlings were placed around the experimental layout to serve as protection rows of reducing border effects.

3) Seedlings were grown for six months inside a shadehouse at the nursery; watering and fertilization was applied as needed.

Although the experimental design for both test sites are notoriously different in number of seedlings per plot (47 seedlings at Ixtlán and 3 at Quebec), note that such difference is partially compensated by an opposite relation of number of blocks (3 blocks at Ixtlán and 18 at Quebec). Thus, the total initial number of seedlings that represented each provenance in each test site was: 147 at Ixtlán and 54 seedlings at Quebec. We consider these sample sizes large enough to have a robust estimation of the variance among provenances within test sites, particularly considering that environmental conditions at Quebec were more controlled than at Ixtlán.

Seedling total height was measured at both locations when seedlings were 6-months-old (October 2007 at Quebec, May 2008 at Ixtlán).

In order to test the significance of variation between locations, among populations, and the interaction population $\mathrm{x}$ location (that can be interpreted as genotype $x$ environment interaction), an analysis of variance was conducted using PROC GLM of SAS (SAS Institute, 1999), with the following full model:

$$
Y_{i j k l}=\mu+\lambda_{i}+p_{j}+b_{k}+u_{i j}+v_{i j k}+e_{i j k l . . .(\text { Eqn. 1) }}
$$

Where $Y_{i j k l}=$ observation on the $l^{\text {th }}$ seedling (Ixtlán: $l$ $=1,2, \ldots, 49$; Quebec: $l=1,2$, or 3$)$ of the $k^{\text {th }}$ block (Ixtlán: $k=1,2$ or 3; Quebec: $k=1,2, \ldots, 24$ ) of the $j^{\text {th }}$ population $(j=1, \ldots, 13)$ of the $i^{\text {th }}$ location $(i=1$ or $2) ; \mu=$ overall mean; $\lambda_{i}=$ fixed effect of the $i^{t h}$ location ( $i=1$ or 2$) ; p_{j}=$ random effect of the $j^{\text {th }}$ population, assuming that $p_{i}$ is an observation from a normal distribution with mean zero and variance $\sigma_{p}^{2} ; b_{k}=$ random effect of $k^{\text {th }}$ block nested in the $i^{\text {th }}$ location, assuming that $b_{k} \sim \mathrm{N}\left(0, \sigma_{k}^{2}\right) ; u_{i j}=$ random effect due to the interaction of location $i$ with population $j$, assuming that $u_{i j} \sim \mathrm{N}\left(0, \sigma_{u}^{2}\right) ; v_{i j k}=$ random effect due to the interaction of population $j$ with block $k$ at location $i$, assuming that $v_{i j l} \sim \mathrm{N}\left(0, \sigma^{2} v\right)$; and $e_{i j k l}=$ random error term associated with the $l^{\text {th }}$ seedling of the provenance $j$ in the location $i$ and measured in the block $k$, assuming that $e_{i j k l} \sim \mathrm{N}\left(0, \sigma_{e}^{2}\right)$.

The relative magnitude of the genotype $\mathrm{x}$ environment interaction was evaluated as type $\mathrm{B}$ genetic correlation ( $\mathrm{r}_{\mathrm{B}}$; Burdon, 1977) submitting standardized data to analysis of variance using Eqn. 1 (Isik et al., 2000) with the following formula:

$$
r_{B}=\sigma_{p}^{2} / \sigma_{p}^{2}+\sigma^{2} u_{\ldots \ldots \ldots \ldots . . . . .(E q n . ~ 2)}
$$

In order to test the significance of variation among populations for each location, data collected on each location were also submitted separately to analysis of variance using the following reduced model:

$$
Y_{j k l}=\mu+p_{j}+b_{k}+v_{j k}+e_{j k l . \ldots \ldots . .(\text { Eqn. 3) }}
$$

Where $Y_{j k l}=$ observation on the $l^{\text {th }}$ seedling of the $k^{\text {th }}$ block of the $j^{\text {th }}$ population; $\mu=$ overall mean; $p_{j}=$ random effect of the $j^{\text {th }}$ population, assuming that $p_{i}$ is an observation from a normal distribution with mean zero and variance $\sigma_{p}^{2} ; \quad b_{k}=$ random effect of $k^{\text {th }}$ block, assuming that $b_{k} \sim \mathrm{N}\left(0, \sigma^{2} k\right) ; v_{j k}=$ random effect due to the interaction of population $j$ with block $k$, assuming that $v_{i j l} \sim \mathrm{N}\left(0, \sigma_{v}^{2}\right)$; and $e_{j k l}=$ random error term associated with the $l^{t h}$ seedling of the provenance $j$ measured in the block $k$, assuming that $e_{j k l} \sim \mathrm{N}\left(0, \sigma_{e}^{2}\right)$.

Contribution to total variance of each variance component was estimated using Proc VARCOMP of SAS, with the REML Method (SAS Institute, 1999). To 
test for altitudinal patterns of genetic variation among populations, least square means by population were regressed on provenance altitude using PROC REG of SAS (SAS Institute, 1999).

\section{RESULTS AND DISCUSSION}

\section{Differences between locations}

Overall, seedling average height across provenances was three times larger at Quebec $(407.9 \pm 7.0 \mathrm{~mm})$ than at Ixtlán $(134.7 \pm 5.7 \mathrm{~mm}$ ) (Figure 1), a difference that was significant $(\mathrm{P}<0.0001 ;$ Table 2$)$. It seems that the growing conditions in the greenhouse located at Quebec favoured growth in seedling height as compared with outdoor climate at the forest nursery in Ixtlán, where the average monthly temperatures were around $15{ }^{\circ} \mathrm{C}$ between November and February. Also, the type of substrate, amount of light and water, temperature and fertilization regime which varied between locations could have positively influenced seedling growth in the Quebec greenhouse.

\section{Differences among populations}

Significant differences among populations were detected in the combined (both sites, Eqn. 1) datasets analysis $(P=0.025$; Table 2$)$. Similar results were obtained when data from each location were analyzed separately (Eqn. 3), that is $\mathrm{P}=0.0325$ and $\mathrm{P}<0.0001$ for Ixtlán and Quebec, respectively (Table 3). Populations explained $5.8 \%$ of the total phenotypic variation when data of both locations were combined (Table 2), and 5.6 and $5.3 \%$ for Ixtlán and Quebec, respectively when an analysis by location was conducted (Table 3).

The population $\mathrm{x}$ location interaction was not significant $(\mathrm{P}=0.426$; Table 2$)$. The best population at Ixtlán was also the best at Quebec, and some of the worst populations at Ixtlán were also the worst at Quebec (Figure 1). Variation due to blocks was significant in the combined analysis $(\mathrm{P}<0.0001$; Table 2$)$, and was significant for the test at Quebec $(\mathrm{P}<0.0001)$ but not for the test at Ixtlán (Table 3).

The multiple means comparison test (Least Significant Difference, $\mathrm{P} \leq 0.05$; Table 4) and the plotting of population means against provenance altitude, revealed that the population originated at $2650 \mathrm{~m}$ of altitude was the one of best growth for seedling height, in both the combined analysis (Figure 2a) and on the analysis by site
(Figures $2 \mathrm{~b}$ and $2 \mathrm{c}$ ). The superiority of this population was more evident at the Quebec test (Figure 2c).

Table 2. Percentage of contribution to total variance (\%) and significance level $(\mathbf{P})$ after an analysis of variance combining results from the two localities (Ixtlán and Quebec), of 6-month-old seedlings from 13 Pinus patula populations.

\begin{tabular}{lrrr}
\hline Source of variation & \multicolumn{1}{c}{ df } & \multicolumn{1}{c}{$\%$} & \multicolumn{1}{c}{ P } \\
\hline Localities & 1 & ----- & $<0.0001$ \\
Populations & 12 & 5.76 & 0.0250 \\
Block (Location) & 25 & 7.74 & $<0.0001$ \\
Population x Location & 12 & 0.51 & 0.4264 \\
Population x Block (Location) & 300 & 23.30 & $<0.0001$ \\
Error & 2281 & 62.69 & \\
\hline
\end{tabular}

$\mathrm{df}=$ degrees of freedom; $\mathrm{P}=$ probability.

Regression analysis of overall population means against altitude of the provenances indicates that, although weak, there is a trend where populations originated at midaltitude have a slightly higher growth potential (expressed as larger total seedling height) than those populations originated from both altitudinal extremes (upper and lower). However, such trend was not found significant (quadratic model, $\mathrm{R}^{2}=0.159 ; \mathrm{P}=0.421$; Figure 2a). The pattern was not significant either (Ixtlán: $\mathrm{R}^{2}=$ $0.132 ; \mathrm{P}=0.492$; Figure 1b; Quebec: $\mathrm{R}^{2}=0.127 ; \mathrm{P}=$ 0.508 ; Figure $2 \mathrm{c}$ ) in the single site analysis.

The lack of significant genotype $\mathrm{x}$ environment interaction, and the fact that the population originated at $2650 \mathrm{~m}$ of altitude was by far the best population at the two locations tested, is an indication that genotypes were phenotypically stable (Karlsson et al., 2001; SánchezVargas et al., 2004; Koo et al., 2007). This is confirmed by the high value of type $B$ genetic correlation $\left(\mathrm{r}_{\mathrm{B}}=\right.$ 0.93). High values of type $B$ genetic correlations have been used as indicators of low genetic $\mathrm{x}$ environment interaction, as it was found when breeding regions for Pinus brutia (Isik et al., 2000), were compared where the type B genetic correlation across sites was considered relatively high.

The weak tendency for seedlings from mid-altitudinal populations to be taller, is similar to the one found for Pinus pseudostrobus in common garden tests conducted at two contrasting locations (Morelia, Michoacán, México and Moscow, Idaho, USA) (Saénz-Romero et al., Com. pers. ${ }^{1}$ ), where mid-altitudinal population produced taller

\footnotetext{
${ }^{1}$ Sáenz-Romero C, G E Rehfeldt, J C Soto-Correa, S AguilarAguilar,V Zamarripa-Morales, J López-Upton (2005) Variación genética altitudinal entre poblaciones de Pinus pseudostrobus. Análisis preliminar de una prueba en dos localidades en casas de sombra. Memorias del VII Congreso Mexicano de Recursos Naturales. Soc. Mex. de Recursos Naturales. Chihuahua, Chih., 26-28 octubre 2005. pp:384-349.
} 
Table 3. Percentage of contribution to total variance (\%) and significance level (P) after an analysis of variance by each locality, of 6-month-old seedlings from 13 Pinus patula populations.

\begin{tabular}{|c|c|c|c|c|c|c|}
\hline \multirow[b]{2}{*}{ Source of variation } & \multicolumn{3}{|c|}{ Ixtlan } & \multicolumn{3}{|c|}{ Quebec } \\
\hline & $\mathrm{df}$ & $\%$ & $\mathrm{P}$ & df & $\%$ & $\mathrm{P}$ \\
\hline Populations & 12 & 5.57 & 0.0325 & 12 & 5.29 & $<0.0001$ \\
\hline Block & 2 & 0.55 & 0.2884 & 23 & 5.73 & $<0.0001$ \\
\hline Population x Block & 24 & 13.40 & $<0.0001$ & 276 & 6.68 & 0.0230 \\
\hline Error & 1683 & 80.48 & & 598 & 82.31 & \\
\hline
\end{tabular}

$\mathrm{Df}=$ degrees of freedom; $\mathrm{P}=$ probability.

Table 4. Least square means (mm) by population, after a combined analysis and by analysis preach location. Letters indicate grouping after Tukey test $(\alpha=0.05)$. Means are sorted in descending order after the combined analysis (Tukey, 0.05)

\begin{tabular}{|c|c|c|c|c|c|c|c|}
\hline \multirow[b]{2}{*}{ Altitude } & \multirow[b]{2}{*}{ Population } & \multicolumn{2}{|c|}{ Combined } & \multicolumn{2}{|c|}{ Ixtlán } & \multicolumn{2}{|c|}{ Quebec } \\
\hline & & Mean & Tukey & Mean & Tukey & Mean & Tukey \\
\hline 2650 & 8 & 303 & $\mathrm{a}$ & 156 & $\mathrm{a}$ & 450 & $\mathrm{a}$ \\
\hline 2450 & 12 & 284 & $a b$ & 146 & $a b$ & 421 & $a b$ \\
\hline 2600 & 9 & 276 & $a b$ & 143 & $a b$ & 410 & $a b c$ \\
\hline 2700 & 7 & 275 & $a b$ & 142 & $a b$ & 409 & $\mathrm{bc}$ \\
\hline 2800 & 5 & 274 & $a b$ & 146 & $a b$ & 402 & $\mathrm{bc}$ \\
\hline 2750 & 6 & 272 & $a b$ & 130 & $a b$ & 414 & $\mathrm{bc}$ \\
\hline 2500 & 11 & 271 & $a b$ & 136 & $a b$ & 406 & $\mathrm{bc}$ \\
\hline 2900 & 3 & 270 & $a b$ & 137 & $a b$ & 404 & $\mathrm{bc}$ \\
\hline 3000 & 1 & 269 & $a b$ & 130 & $a b$ & 408 & $\mathrm{bc}$ \\
\hline 2950 & 2 & 267 & $a b$ & 128 & $a b$ & 406 & $\mathrm{bc}$ \\
\hline 2850 & 4 & 257 & $\mathrm{~b}$ & 133 & $a b$ & 380 & $\mathrm{bc}$ \\
\hline 2550 & 10 & 256 & $\mathrm{~b}$ & 105 & $a b$ & 407 & $\mathrm{bc}$ \\
\hline 2400 & 13 & 252 & b & 120 & $\mathrm{~b}$ & 385 & c \\
\hline
\end{tabular}

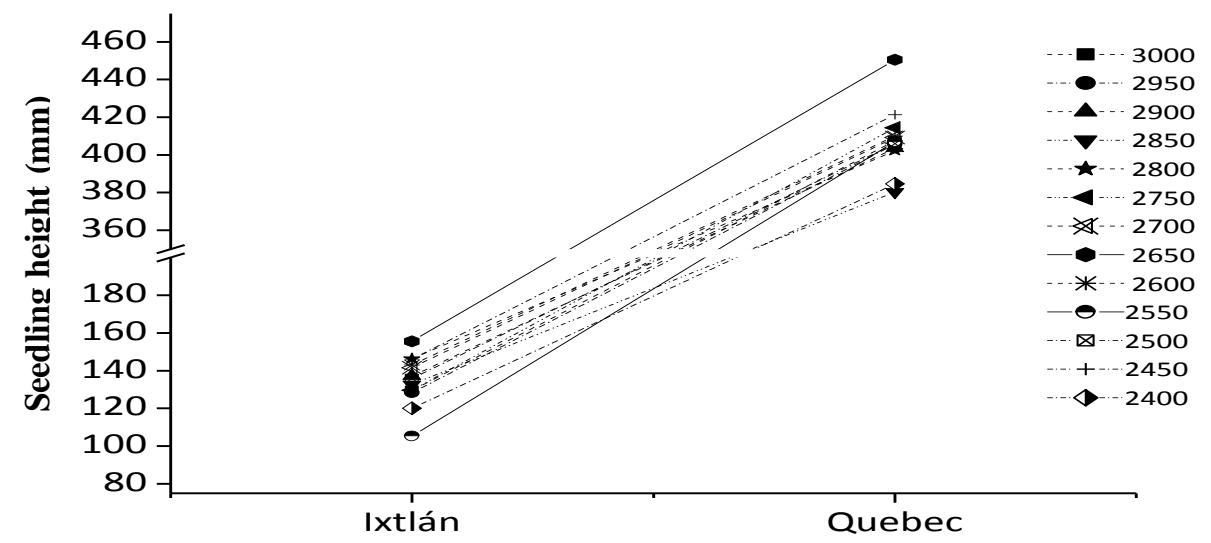

Location

Figure 1. Least square means of height $(\mathrm{mm})$ of Pinus patula seedlings, by location and by population of 6-month-old seedlings from tests at Ixtlán de Juárez, Oaxaca, México and at Quebec, Canada.

seedlings although such trend was not statistically significant. Other species have shown this pattern more clearly: populations from mid-altitude showed the best growth at 6 years-old seedlings of Pinus brutia (Isik and Kara, 1997); P. oocarpa populations from middle-low altitudes exhibited the best basal diameter at 6 months
(Sáenz-Romero et al., 2004) and the largest seedling height at 2.5 years of age (Sáenz-Romero et al., 2006).

There are indications that $P$. patula populations from lower altitudes grow more than populations from higher altitudes; however, those results come from studies where 


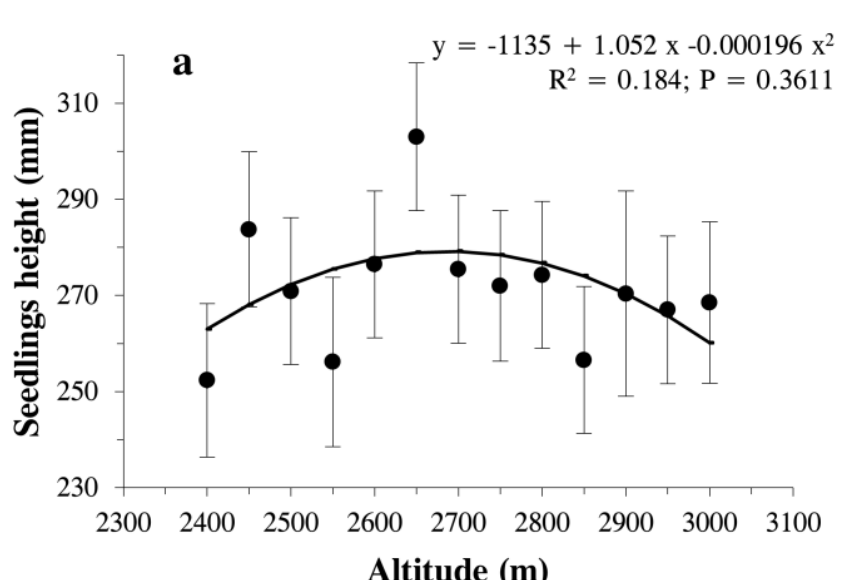

Altitude (m)
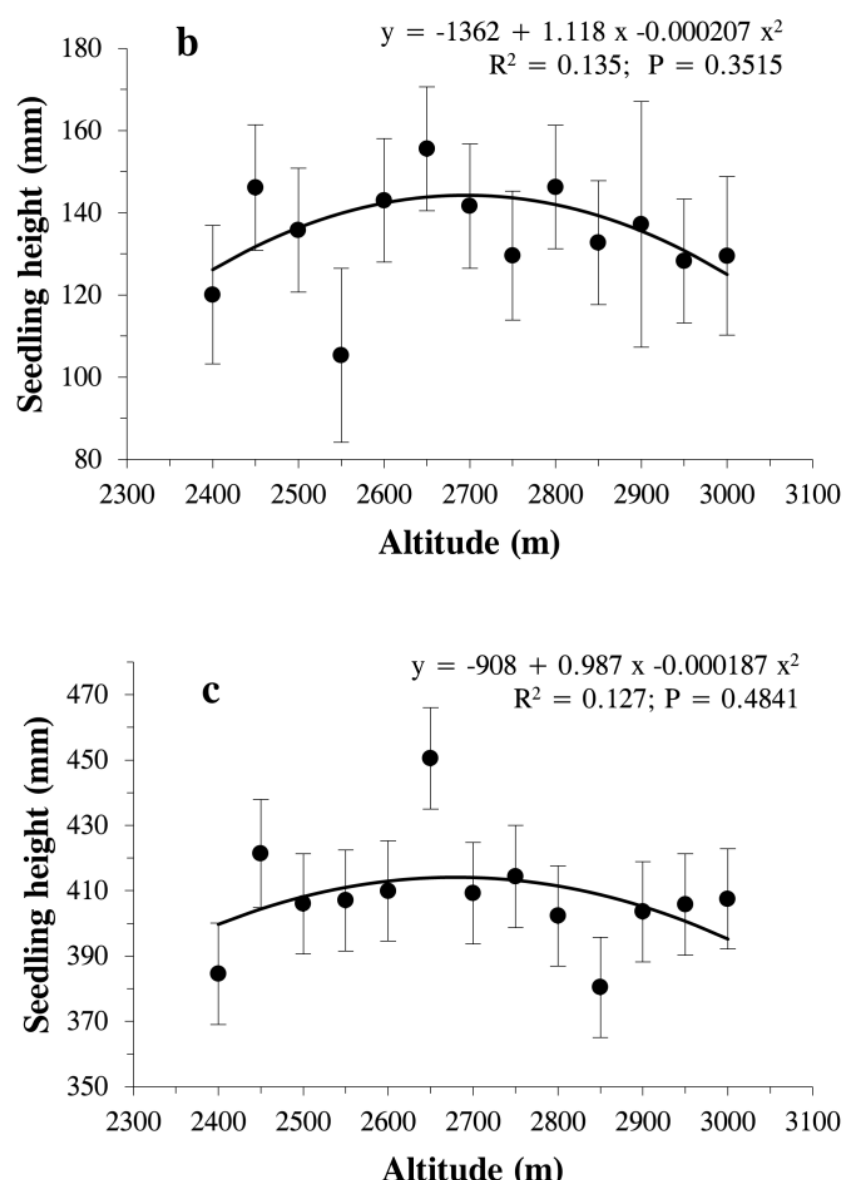

Figure 2. Least square means of height $(\mathrm{mm})$ of pinus patula seedlings, by population of 6-month-old seedlings plotted against provenance elevation (masl). (a) Overall means from combined analysis, (b) Means from test at Ixtlán de Juárez, Oaxaca, México, (c) Means from test at Quebec, Canada. Vertical bars indicate confidence intervals $(95 \%)$.

provenances of different altitudes came also from different latitudes (Salazar-García et al., 1999; Dvorak et al., 2000), thus making difficult to establish clearly how much of the genetic variation among populations is associated with the altitudinal origin, because it would be needed to study several provenances from different altitudes and similar latitudes. An ongoing field test of the same set of $P$. patula populations as those used in the present study, was recently established on two contrasting altitudes in the forest of Ixtlán de Juárez, Oaxaca. Hence, in a few years it will be possible to confirm whether population stability is maintained over time, and if the altitudinal pattern that was reported here would be expressed at later ages.

\section{CONCLUSIONS}

There was significant genetic differentiation among populations of 6-months-old seedlings for total height. However there was not a significant genotype $\mathrm{x}$ environment interaction $\left(\mathrm{r}_{\mathrm{B}}=0.93\right)$. The population

sampled at $2650 \mathrm{~m}$ of altitude (middle) had the largest value of total seedling height.

A weak altitudinal pattern was found where populations originating from middle altitudes exhibited the highest growth potential and populations from the upper and lower altitudinal extremes exhibited lower growth potential.

\section{ACKNOWLEDGEMENTS}

Financial support was provided to CSR by the joint Forestry Research Fund between the Mexican Council of Science and Technology (CONACYT) and the Mexican National Forestry Commission (CONAFOR, grant 2005C02-14783). Funding for a sabbatical year was provided by the Natural Resources Canada (NRCan) and CONACYT (fellowship 75831). For their help in seed collection we thank to Antonio Plancarte, Julio Ruiz, Samuel Ramírez, Mauro and Eduardo Aquino, and Mayolo Ruiz from the Native Indian Community of Ixtlán de Juárez, Oaxaca; to Rodrigo Niniz for helping in seed extraction and to Víctor Hugo Cambrón for helping on graph design, both from UMSNH. Experiment at Quebec was possible thanks to Daniel Plourde, Eric Dussault, Audrey Lachance, Gabriel Pilote from NRCan. Three anonymous reviewers significantly contributed to improve the manuscript. 


\section{BIBLIOGRAPHY}

Adams W T, S N Aitken, D G Joyce, G T Howe, J J VargasHernández (2001) Evaluating efficacy of early testing for stem growth in coastal Douglas-fir. Silvae Genet. 50:167-175.

Burdon R D (1977) Genetic correlation as a concept for studying genotype-environment interaction in forest tree breeding. Silvae Genet. 26:168-175.

Dvorak W S, G R Hodge, J E Kietzka, F Malan, L F Osorio, T K Stangen (2000) Pinus patula. In: Conservation and Testing of Tropical and Subtropical Forest Tree Species by the CAMCORE Cooperative. CAMCORE Cooperative (ed). North Carolina State University, Raleigh, NC. pp:149-173.

Isik K, N Kara (1997) Altitudinal variation in Pinus brutia Ten. and its implication in genetic conservation and seed transfers in southern Turkey. Silvae Genet. 46:113-120.

Isik K, F L Keskin, S E McKeand (2000) Provenance variation and provenance-site interaction in Pinus brutia Ten.: Consequences of defining breeding zones. Silvae Genet. 49:213-223.

Karlsson B, H Wellendorf, H Roulund, M Werner (2001) Genotype $\mathrm{x}$ trial interaction and stability across sites in 11 combined provenance and clone experiments with Picea abies in Denmark and Sweden. Can. J. For. Res. 31:1826-1836.

Koo Y B, J K Yeo, K S Woo, T S Kim (2007) Selection of superior clones by stability analysis of growth performance in Populus davidiana Dode at age 12. Silvae Genet. 56:93-101.

Lambeth C C, J P van Buijtenen, S D Duke, R B McCullough (1983) Early selection is effective in 20-year-old genetic tests of loblolly pine. Silvae Gen. 32:210-215.

Martínez-Guzmán A, S Colín-Castillo (2003) La certificación ambiental de los bosques en México: reporte preliminar. Gaceta Ecol. 67:45-60.
Rehfeldt G E (1991) A model of genetic variation for Pinus ponderosa in the Inland Northwest (USA): applications in gene resource management. Can. J. For. Res. 21:1491-1500.

Rehfeldt G E, C C Ying, D L Spittlehouse, D A Jr Hamilton (1999) Genetic responses to climate in Pinus contorta: niche breadth, climate change, and reforestation. Ecol. Monog. 69: 375-407.

Sáenz-Romero C, H Viveros-Viveros，R Guzmán-Reyna (2004) Altitudinal genetic variation among Pinus oocarpa populations on Michoacán, western México. Preliminary results from a nursery test. For. Genet. 11:343-349.

Sáenz-Romero C, R Guzmán-Reyna, G E Rehfeldt (2006) Altitudinal genetic variation among Pinus oocarpa populations in Michoacán, México; implications for seed zoning, conservation of forest genetic resources, tree breeding and global warming. For. Ecol. Manage. 229:340-350.

Sánchez-Vargas N M, J J Vargas-Hernández, L M Ruiz-Posadas, J López-Upton (2004) Repeatability of genetic parameters in a clonal test of Eucalyptus urophylla S. T. Blake in Southeastern México. Agrociencia 38:465-475.

SAS Institute (1999) SAS/STAT User Guide. Version 8. SAS Institute Inc. Cary, N C. 3rd ed. 3809 p.

Velázquez-Martínez A, G Angeles-Pérez, T Llanderal-Ocampo, A R Román-Jiménez, V Reyes-Hernández (2004) Monografía de Pinus patula. Comisión Nacional Forestal, México.

Viveros-Viveros H, C Sáenz-Romero, R Guzmán-Reyna (2005) Genetic control of Pinus oocarpa seedlings growth traits in the nursery. Rev. Fitotec. Mex. 28:333-338.

Zobel B J, J T Talbert (1992) Técnicas de Mejoramiento Genético de Árboles Forestales. Ed. Limusa. México, D. F. 545 p. 